\title{
Perlindungan Hukum bagi Pekerja Anak: Tinjauan Perspektif Keadilan dan Kesejahteraan Anak
}

\author{
Meirina Nurlani* \\ Universitas Sjakhyakirti, Palembang, Indonesia
}

\begin{abstract}
Increasing economic demands shape the situation of a child having to work to help his parents to support his family's economy. Therefore, it is necessary to provide legal protection for child labor. Legal protection for child labor is an important instrument that must be considered by the government; considering that the guarantee of legal protection is a moral responsibility for the government to fulfill the welfare and justice of child workers. This type of research is legal research. This legal research uses a statute approach and conceptual approach. The legal materials used in this legal research are primary and secondary legal materials. The results of this study state that legal protection for child labor is based on various laws and regulations. The welfare of child workers will be obtained when the rights of child workers as stated in various laws and regulations are fulfilled and guaranteed by the company. Prosperity in this study does not only have material meaning, but includes non-material aspects; as well as continuing to provide flexibility for children to continue to develop their capacity. Furthermore, regarding justice, child workers should also be given legal protection; considering that children are human beings who have human rights. Tackling the problem of child labor can be done using three efforts; namely preventive efforts, curative efforts, and repressive measures. On the other hand, an integrated planning is needed to deal with the problem of child labor. This sustainable planning is carried out to fulfill various fundamental rights of child labor.
\end{abstract}

KEYWORDS: Child Workers, Child Rights, Legal Protection for Child Workers.

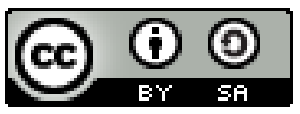

Copyright (C) 2021 by Author(s)

This work is licensed under a Creative Commons Attribution-ShareAlike 4.0 International License. All writings published in this journal are personal views of the authors and do not represent the views of this journal and the author's affiliated institutions.

HOW TO CITE:

Meirina, Nurlani, "Perlindungan Hukum Bagi Pekerja Anak: Tinjauan Perspektif Keadilan dan Kesejahteraan Anak" (2021) 1:1 Jurnal Kajian Pembaruan Hukum 107-132. DOI: <https://doi.org/10.19184/jkph.v1i1.23397>.

Submitted: 26/02/2021 Reviewed: 01/03/2021 Revised: 07/03/2021 Accepted: 11/03/2021

\footnotetext{
* Corresponding authors' e-mail: meirinanurlani05@gmail.com
} 


\section{PENDAHULUAN}

Anak adalah generasi penerus bangsa yang diharapkan dapat membangun Negara menjadi lebih baik di masa depan. Akan tetapi, sebagai makhluk sosial yang paling rentan dan lemah; ironisnya anak-anak justru sering kali di tempatkan dalam posisi yang paling di rugikan, seperti halnya tidak memiliki hak untuk bersuara dan bahkan mereka sering menjadi korban tindak kekerasan. ${ }^{1}$ Padahal, pengakuan terhadap hak anak secara internasional dilakukan oleh Perserikatan Bangsa-bangsa melalui Convention on the Rights of The Child (CRC) pada tahun 1989.2 Konvensi tersebut menyebutkan bahwa anak adalah pemegang hak - hak dasar kebebasan maupun sebagai pihak yang menerima perlindungan khusus. CRC menyebutkan bahwa suatu hak anak lahir dari kesadaran bahwa seorang anak sejatinya dapat dikatakan rentan, tergantung, lugu, dan memiliki kebutuhan-kebutuhan khusus. ${ }^{3}$

Meninjau urgensi dari konvensi ini, Indonesia langsung merespon dengan meratifikasi CRC pada tahun 1990 yang di tuangkan dalam Keputusan Presiden Nomor 36 Tahun 1990 tertanggal 25 Agustus 1990, dan dinyatakan berlaku di Indonesia sejak tanggaI 5 Oktober 1990. ${ }^{4}$ Indonesia meratifikasi isi konvensi ini karena CRC dianggap menyuarakan hal-hal dasar mengenai perlindungan anak. Perlindungan pada anak perlu dilakukan agar anak dalam proses tumbuh dan kembangnya menjadi lebih maju. Di sisi lain, sebagai

1 Arif Gosita, Masalah perlindungan Anak (Jakarta: Sinar Grafika, 1992).

2 Nada Kusuma \& Santoso Tri Raharjo, “Penanganan Masalah Pekerja Anak Melalui Pemberdayaan Organisasi Lokal 'Forum Peduli Anak' Di Kelurahan Cibeureum Kota Cimahi" (2016) 6:1 Share Soc Work J.

3 Anna Holzscheiter, Jonathan Josefsson \& Bengt Sandin, "Child rights governance: An introduction" (2019) 26:3 Childhood 271-288 at 275.

4 Rini Fitriani, "Peranan Penyelenggara Perlindungan Anak dalam Melindungi dan Memenuhi Hak-Hak Anak" (2016) 11:2 J Huk Samudra Keadilan 250-258 at 251 . 
bagian dari masyarakat bangsa, anak juga memiliki hak yang berguna dalam menjamin pertumbuhan dan perkembangannya. ${ }^{5}$

Oleh karena itu, seorang anak memerlukan perawatan dan perlindungan yang khusus; baik secara fisik maupun mental. Berbicara tentang anak, tentunya ada anak yang dalam kondisi tertentu untuk melakukan kegiatan bekerja. ${ }^{6}$ Temuan Muhammad Saiful Rahman menyebutkan bahwa pekerja anak adalah anak-anak yang berusia 4 (empat) hingga 18 (delapan belas) tahun yang bekerja diberbagai bidang pekerjaan yang berkelanjutan dan menyita hampir seluruh waktu mereka sebagai anak sehingga tidak dapat bersekolah seperti anak-anak lainnya secara normal. ${ }^{7}$ Akan tetapi, hal tersebut berbeda dengan kondisi masyarakat yang berada di garis kemiskinan; tuntutan ekonomi yang mendesak membuat mereka diharuskan bekerja dan putus sekolah pada usia dini.

Fenomena pekerja anak erat kaitannya dengan kemiskinan sebagaimana yang dikemukakan oleh Grootaert dan Kanbur (1995); yang menyatakan terdapat empat hal penentu (determinants) anak yang bekerja. Pertama, jumlah anak dalam rumah tangga merupakan faktor penentu yang potensial (potential determinats) penawaran pekerja anak di pasar kerja; karena itu perilaku fertilitas sangat berpengaruh dalam penawaran pekerja anak. Hasil penelitian yang dilakukan di beberapa negara berkembang menunjukkan bahwa

5 James Cooper, "Child Labour: Legal Regimes, Market Pressures, and the Search for Meaningful Solutions" (1997) 52:3 Int J 411.

6 Netty Endrawati, "Perlindungan Hukum Terhadap Pekerja Anak Di Sektor Informal (Studi Kasus Di Kota Kediri)" (2012) 12:2 J Din Huk.

7 Kanyaka Prajnaparamita, "Perlindungan Tenaga Kerja Anak" (2018) 1:2 Adm Law Gov J 215-230 at 218.

8 Hasrul Mahadi Lubis \& Arifin Saleh, "Pekerja Anak Sebagai Buruh Batu Bata di Kelurahan Silandit Kota Padang Sidimpuan" (2020) 1:1 J Interv Sos dan Pembang 29-43 at 38. 
makin besar jumlah keluarga akan mengurangi partisipasi sekolah anak-anak. ${ }^{9}$ Dengan kata lain, makin besar jumlah anggota keluarga; akan meningkatkan risiko anak-anak untuk bekerja pula. Kedua, penyebab anak-anak bekerja adalah berkaitan dengan risiko pendapatan rumah tangga. Pada rumah tangga yang termasuk ke dalam kategori miskin, mereka cenderung mengijinkan anak-anak untuk masuk ke dalam pasar kerja guna meminimalkan terhentinya arus pemasukan pendapatan rumah tangga. Oleh karena itu, anakanak yang bekerja menjadi salah satu harapan sekaligus solusi menghadapi keadaan ekonomi keluarga. ${ }^{10}$

Ketiga, perihal struktur pasar kerja yang berkaitan dengan pengupahan. Pada pasar kerja yang kompetitif, upah bersifat fleksibel; sehingga pekerja anak dapat mensubtitusi pekerja dewasa. Pada berbagai penelitian di negara berkembang, ditemukan bahwa dalam jenis pekerjaan tertentu, pengusaha lebih menyukai pekerja anak daripada pekerja dewasa; ${ }^{11}$ dengan alasan pekerjaan itu justru tidak efektif jika dikerjakan oleh orang dewasa. Keempat, peranan teknologi. Beberapa hasil penelitian menunjukkan bahwa perubahan teknologi terbukti mengurangi jumlah pekerja anak. ${ }^{12}$ Perubahan teknologi mendorong munculnya pekerja anak; misalnya untuk menekan pengeluaran, perusahaan melakukan subcontracting, yaitu menyerahkan sebagian proses produksi suatu barang kepada penduduk yang berada di sekitar perusahaan untuk dikerjakan di

$9 \quad$ Ibid at 39.

10 Manfred Liebel, "Protecting the Rights of Working Children instead of Banning Child Labour" (2015) 23:3 Int J Child Rights 529-547 at 534.

11 Edward van Daalen \& Karl Hanson, “The ILO's Shifts in Child Labour Policy: Regulation and Abolition" (2019) 1:11 Rev Int Polit développement 133-150 at 147.

12 Pita Jubaningtyas Hardono, "Perlindungan Hukum Terhadap Pekerja Anak Terkait Upah dan Jam Kerja" (2019) 1:2 Jurist-Diction 675. 
rumah. ${ }^{13}$ Hal ini merupakan upaya perusahaan untuk mengurangi berbagai biaya; seperti listrik, asuransi, dan berbagai fasilitas pekerja. Terdapat beberapa faktor lain yang melatarbelakangi seorang anak menjadi pekerja anak. Pertama, faktor ekonomi. Perekonomian keluarga yang rendah merupakan faktor dominan yang menyebabkan anak terlibat mencari nafkah guna memenuhi kebutuhan keluarga yang tidak terpenuhi dari hasil kerja orangtua. Kedua, faktor urbanisasi. Daerah asal dari pekerja anak -yang mayoritas dari pedesaan- merupakan salah satu faktor timbulnya pekerja anak. Pedesaan yang dianggap tidak bisa memberikan jaminan perbaikan ekonomi, mendorong banyak orang mengadu nasib ke kota-kota besar dengan harapan dapat memperoleh penghasilan yang lebih tinggi. Ketiga, faktor sosial budaya. Kadangkala anak yang bekerja justru dianggap sebagai anak yang berbakti dan dapat mengangkat harkat dan martabat orang tua. Keempat, faktor pendidikan. Keterbelakangan mereka untuk mengenyam pendidikan menjadi problem legitimasi sosial; mengingat standar kapasitas akademik dilingkup sosial ditinjau dari seberapa tinggi anak dapat mengenyam pendidikan. ${ }^{14}$ Berbagai faktor tersebut menjadi alasan adanya pekerja anak. Oleh karena itu, perlindungan hukum bagi pekerja anak adalah konsekuensi moral dari tanggung jawab negara terhadap masyarakat. ${ }^{15}$

Perlindungan hukum bagi anak sejatinya dimulai sejak anak tersebut masih dalam rahim ibunya; hingga anak tersebut mencapai usia dewasa. Anak juga diberi perlindungan agar sedapat mungkin

13 Made Dharma Laksana Swastika, I Nyoman Putu Budiartha \& Desak Gde Dwi Arini, "Perlindungan Hukum bagi Pekerja Anak di Indonesia" (2020) 1:1 J Interpret Huk 101-105 at 102.

14 Zeynep Şişli \& Stephanie A Limoncelli, "Child brides or Child Labor in a Worst Form?" (2019) 22:2 J Labor Soc 313-324 at 320.

15 Ibid at 321. 
dihindarkan sebagai korban suatu tindak pidana. Oleh karena, perlindungan anak dalam berbagai aspek dilakukan melalui penyusunan peraturan perundang-undangan mengenai perlindungan hukum bagi anak itu sendiri. Namun, perlindungan hukum bagi pekerja anak acapkali dianggap kurang diperhatikan oleh para pengusaha; ${ }^{16}$ mengingat pekerja anak dianggap kurang memiliki pengalaman. Di sisi lain, pekerja anak dianggap belum memiliki daya tawar yang tinggi di dunia kerja. ${ }^{17}$ Terlebih, mental dan fisik anak seringkali diasumsikan sangat lemah, ${ }^{18}$ sehingga tidak mampu untuk bersaing secara kontinu dalam dunia kerja.

Berdasarkan berbagai hal di atas, adapun isu hukum yang ingin penulis kaji dalam penelitian ini adalah (1) Bagaimanakah bentuk Perlindungan Hukum yang akan didapatkan oleh Pekerja Anak?; dan (2) Apakah bentuk upaya yang dilakukan oleh pihak terkait guna menanggulangi permasalahan pekerja anak? Penelitian mengenai pekerja anak sejatinya telah dilakukan oleh beberapa penulis sebelumnya. Pertama, penelitian oleh Solehuddin (2013) yang berjudul Pelaksanaan Perlindungan Hukum Terhadap Pekerja Anak Yang Bekerja Di Bidang Konstruksi (Studi di Proyek Pembangunan CV. Karya Sejati Kabupaten Sampang) yang menyatakan bahwa belum ada perlindungan hukum terhadap pekerja anak yang bekerja di bidang konstruksi. Kedua, penelitian Pita Jubaningtyas (2018) yang berjudul Perlindungan Hukum Terhadap Pekerja Anak Terkait Upah dan Jam Kerja yang menyatakan bahwa pengaturan hukum mengenai pekerja anak

16 Şişli \& Limoncelli, supra note 14.

17 Tri Sulistiyono \& Lowrenszya Siagian, The Phenomenon of Child Labour: Causes, Consequences, and Protection under Indonesian Law (Paris, France: Atlantis Press, 2019).

18 Mohammad Shahidul Islam \& Md Abdur Rakib, "Labour Laws in the Garment Sector of Bangladesh: a Workers' View" (2019) 34:3 Yuridika 467. 
di Indonesia tidak memiliki undang-undang tersendiri, melainkan menjadi satu dengan pekerja dewasa.

Dengan demikian, penelitian berjudul Perlindungan Hukum bagi Pekerja Anak Ditinjau dari Perspektif Keadilan dan Kesejahteraan Anak berbeda dengan dua penelitian di atas. Oleh sebab, penelitian ini menganalisis dan menjelaskan perlindungan hukum bagi pekerja anak ditinjau dari perspektif keadilan dan kesejahteraan anak dan menganalisis serta mengembangkan upaya apa yang akan dilakukan oleh pihak terkait guna menanggulangi permasalahan pekerja anak sebagai bentuk dari perlindungan hukum bagi pekerja anak. Manfaat Ilmiah yang diperoleh dari penelitian ini terbagi atas 2 (dua); yaitu manfaat teoritis dan manfaat praktis.

Manfaat teoritis penelitian ini adalah diharapkan bermanfaat untuk memberikan sumbangan pemikiran dalam bidang kajian hukum ketenagakerjaan; yang berkaitan dengan perlindungan hukum bagi pekerja anak. Sedangkan manfaat praktis penelitian ini adalah diharapkan dapat bermanfaat secara praktis bagi berbagai pihak. Bagi pemerintah, diharapkan penelitian ini dapat dijadikan sebagai acuan untuk menyusun peraturan mengenai pekerja anak. Bagi para akademisi hukum, penelitian ini dapat dijadikan sebagai tambahan kepustakaan dalam khazanah hukum ketenagakerjaan, khususnya hukum ketenagakerjaan bagi anak mengenai perlindungan hukum bagi pekerja anak ditinjau dari perspektif keadilan dan kesejahteraan anak.

\section{METODE}

Jenis penelitian yang penulis gunakan merupakan penelitian hukum normatif. Penelitian hukum merupakan suatu proses untuk menemukan aturan hukum dan doktrin- doktrin hukum guna 
menjawab isu hukum yang dihadapi. ${ }^{19}$ Berdasarkan hal tersebut, data yang diperoleh oleh penulis dalam hal ini bersumber dari hasil penelitian kepustakaan. Penelitian ini mempergunakan jenis pendekatan perundang-undangan dan juga pendekatan konseptual. Kemudian, bahan hukum yang di pergunakan dalam penelitian ini terbagi atas dua bahan hukum; yaitu bahan hukum primer dan bahan hukum sekunder. Bahan hukum primer yang digunakan dalam penelitian ini adalah Undang-Undang Ketenagakerjaan. Kemudian, bahan hukum sekunder yang digunakan dalam penelitian ini berupa artikel jurnal, buku-buku, tesis, dan juga pendapat dari para sarjana yang mendukung pembahasan di dalam permasalahan ini.

\section{PERLINDUNGAN HUKUM PEKERJA ANAK}

Perlindungan terhadap anak ialah tanggung jawab kita bersama; bukan hanya bagi orang tua, akan tetapi bagi masyarakat dan Negara wajib bertanggung jawab pula. Undang-Undang Nomor 23 Tahun 2002 Tentang Perlindungan Anak (UU Anak) memberikan jaminan atas perlindungan anak; UU tersebut menegaskan bahwa anak harus dijamin dan dilindungi agar anak mendapatkan haknya dalam menikmati hidup, berkembang, terhindar dari kekerasan maupun diskriminasi. ${ }^{20}$ Umumnya, seorang anak memiliki masa-masa tumbuh kembang yang baik dan mendapatkan hak-hak yang memang sejatinya mereka miliki. Akan tetapi, dalam suatu kondisi tertentu, mereka diharuskan untuk bekerja. Menurut suatu survei, ${ }^{21}$

19 Peter Mahmud Marzuki, Penelitian Hukum: Edisi Revisi, 13th ed (Jakarta: Kencana, 2017).

20 Sri Intan Danayanti \& I Gusti Ngurah Wairocana, "Perlindungan Hukum Terhadap Anak di Bawah Umur yang Berprofesi sebagai Artis Berdasarkan Undang-Undang Ketenagakerjaan” (2019) 7:7 Kertha Semaya J Ilmu Huk 1.

21 Arvita Hastarini, “Keabsahan Perjanjian Kerja yang Dilakukan Anak di Bawah Umur" (2019) 25:1 J Wacana Huk 19. 
tingginya jumlah pekerja anak di Indonesia masih menjadi salah satu problem serius yang harus ditangani secara komprehensif. Hal tersebut dapat terlihat dalam Survei Nasional Pekerja Anak oleh Badan Pusat Statistik (BPS) dan International Labour Organization (ILO) dari sekitar 4 (empat) juta anak Indonesia aktif secara ekonomi; terdapat 1,8 juta dari mereka masuk dalam kategori pekerja anak. ${ }^{22}$

Komisi Nasional Perlindungan Anak juga mencatat terdapat 11 (sebelas) juta anak usia 7 (tujuh) sampai dengan 8 (delapan) tahun tidak terdaftar sekolah di 33 (tiga puluh tiga) provinsi di Indonesia. Tingginya jumlah pekerja anak ini membuat ILO menjadikan Indonesia sebagai negara yang menjadi target utama dalam Program Penghapusan Bentuk-bentuk Pekerjaan Terburuk untuk Anak atau International Programme on The Elimination of Child Labour (IPEC). ${ }^{23}$ Terhitung sejak 1992 hingga sekarang, pemerintah Indonesia bersama sejumlah pihak terkait, ${ }^{24}$ baik di tingkat pusat maupun daerah terus mengupayakan mengurangi jumlah pekerja anak secara signifikan, terutama pada sejumlah jenis pekerjaan yang dikategorikan sebagai pekerjaan berbahaya bagi anak.

Sejumlah pekerjaan berbahaya itu antara lain pelacuran, pertambangan, penyelam mutiara, sektor konstruksi, pemulung sampah, pekerjaan dengan proses produksi menggunakan bahan peledak, bekerja di jalan, dan pembantu rumah tangga. ${ }^{25}$ Indonesia termasuk negara yang memiliki komitmen besar untuk menanggulangi masalah pekerja anak; yang ditandai dengan

22 Ibid.

23 Agusmidah Agusmidah \& Suria Ningsih, "A Critical Review of Waging in Indonesian Law" (2016) 3:2 Rechtsidee 61.

24 Danayanti \& Wairocana, supra note 21.

${ }^{25}$ I Gusti Ngurah Winda Aditya Putra, I Nyoman Putu Budiartha \& Luh Putu Suryani, "Akibat Hukum Pekerja Anak Menurut Undang -Undang Nomor 13 Tahun 2003" (2021) 2:1 J Konstr Huk 57-61 at 59. 
keikutsertaan Indonesia dalam program IPEC ILO sejak dua dekade lalu. Indonesia juga turut meratifikasi Konvensi ILO tentang bentukbentuk pekerjaan terburuk untuk anak Nomor 182 dan Konvensi ILO mengenai usia minimum memasuki dunia kerja Nomor $183 .{ }^{26}$

Melalui meratifikasi konvensi tersebut, Indonesia mempertegas komitmennya untuk mengambil tindakan dengan segera dan efektif untuk melarang dan menghapuskan bentuk-bentuk pekerjaan terburuk untuk anak. ${ }^{27}$ Hal ini juga dapat dilihat dari upaya pemerintah untuk menjalin kemitraan yang strategis; mulai dari pemerintah daerah, pihak swasta, lembaga swadaya masyarakat hingga berbagai organisasi internasional. Beberapa pemerintah daerah bahkan dengan tegas memproklamirkan daerahnya sebagai Zona Bebas Tenaga Kerja Anak (ZBTA). ${ }^{28}$

Sejumlah upaya di atas mulai menunjukkan hasil yang cukup menggembirakan. Berdasarkan data ILO, jumlah pekerja anak mulai mengalami penurunan sekitar 3,4 persen setiap tahunnya. ${ }^{29}$ Meski demikian, upaya untuk mewujudkan Indonesia bebas pekerja anak masih sangat panjang. Tingginya angka kemiskinan, kurangnya akses pendidikan, persepsi keluarga tentang pendidikan serta dinamika permintaan akan tenaga kerja dinilai masih akan menjadi hambatan penghapusan pekerja anak secara total. ${ }^{30}$ Tingginya angka kemiskinan seringkali dianggap sebagai salah satu faktor pendorong utama tingginya jumlah pekerja anak di Indonesia; yang mana salah

26 Desia Rakhma Banjarani \& Ricco Andreas, "Perlindungan dan Akses Hak Pekerja Wanita di Indonesia: Telaah Undang-Undang Nomor 13 Tahun 2003 tentang Ketenagakerjaan Atas Konvensi ILO" (2019) 10:1 J HAM 115.

${ }^{27}$ Kartika Dewi Mulyanto, “Urgensi Ratifikasi Konvensi Pekerjaan yang Layak bagi Pekerja Rumah Tangga oleh Pemerintah Indonesia" (2018) 1:1 Undang J Huk 109-133 at 121.

28 Hastarini, supra note 22.

29 Prajnaparamita, supra note 7.

30 Ibid. 
satu dampak kemiskinan yang utama adalah diabaikannya hak-hak anak.

Selain melakukan penarikan dan pencegahan anak secara langsung dari dunia kerja, pendekatan ekonomi kini turut menjadi salah satu strategi utama dalam menanggulangi masalah pekerja anak. ${ }^{31}$ Salah satu yang menjadi prioritas adalah program pengentasan kemiskinan para orang tua melalui berbagai program dari pemerintah, ${ }^{32}$ misalnya Kartu Indonesia Sehat, Kartu Indonesia Pintar, Kartu Keluarga Sejahtera, dan lain sebagainya. Hal ini dikarenakan kemiskinan orang tua bisa menjadi sumber utama munculnya pekerja anak. Kemiskinan yang terus berlanjut juga bisa membuat siklus pekerja anak terus mengalami regenerasi. Pada kasus pekerja anak, banyak di antara mereka bekerja sebagai buruh yang merupakan anak dari orang tua yang dulunya memiliki pekerjaan sebagai buruh pula. ${ }^{33}$

Mereka tidak punya banyak pilihan selain terus menjadi buruh dan ini dapat berlangsung hingga generasi berikutnya. Kondisi tersebut sangat merugikan; mengingat mereka berpotensi mendapatkan upah dengan murah, rentan terhadap eksploitasi, rentan terhadap kecelakaan kerja, rentan terhadap PHK yang semena-mena, serta berpotensi untuk kehilangan akses dan kesempatan mengembangkan diri. ${ }^{34}$ Oleh karena itu, pemerintah harus melakukan upaya perlindungan kepada anak yang terpaksa bekerja melalui peraturan perundang-undangan; agar anak-anak mendapatkan hak-haknya sebagai pekerja pula.

31 Wafda Vivid Izziyana, "Perlindungan Hukum Bagi Pekerja Anak di Indonesia" (2019) 3:2 Leg Standing J Ilmu Huk 103.

32 Sohidin, "Faktor Demografi yang Mempengaruhi Pekerja Anak di Provinsi Kepulauan Bangka Belitung Tahun 2018" (2020) 19:1 J Penelit Kesejaht Sos 4582 at 50.

33 Ibid at 56.

34 Winda Aditya Putra, Budiartha \& Suryani, supra note 26. 
Indonesia telah memiliki seperangkat peraturan perundangundangan untuk menjamin hak-hak anak. Adapun peraturan perundang-undangan tersebut antara lain adalah Undang-undang Dasar Negara Republik Indonesia tahun 1945, Ratifikasi konvensi ILO Nomor 138 menjadi Undang-undang Nomor 20 Tahun 1999 tentang Usia Minimum Untuk Diperbolehkan Bekerja, Ratifikasi konvensi ILO Nomor 182 menjadi undang-undang Nomor 1 Tahun 2000 tentang Pelanggaran dan tindakan segera penghapusan bentukbentuk pekerjaan terburuk untuk anak, Undang-undang Nomor 39 Tahun 1999 Tentang Hak Asasi Manusia (UU HAM), UU Anak, Undang-undang Nomor 13 Tahun 2003 tentang Ketenagakerjaan (UU Ketenaker), Undang-undang Nomor 35 Tahun 2014 tentang Perubahan atas Undang-undang Nomor 23 Tahun 2002 tentang Perlindungan Anak (UU Anak II).

Perlindungan hukum bagi pekerja yang terikat dengan suatu badan atau lembaga telah diatur dalam UU Ketenaker; yang diatur dalam Pasal 68 dan Pasal 75 UU Ketenaker. Secara yuridis, Pasal 68 UU Ketenaker menyatakan bahwa pengusaha atau suatu lembaga dilarang mempekerjakan anak; demikian pula ketentuan Pasal 69 UU Ketenaker memberikan penjelasan bahwa ketentuan ini dikecualikan bagi anak yang berumur 13 (tiga belas) sampai dengan 15 (lima belas) tahun untuk melakukan pekerjaan ringan; sepanjang tidak mengganggu perkembangan dan kesehatan fisik, mental, dan sosialnya.

Perusahaan yang akan mempekerjakan anak dalam lingkup pekerjaan ringan harus memenuhi persyaratan seperti halnya izin tertulis dari orang tua atau wali, perjanjian kerja antara pengusaha dengan orang tua atau wali, waktu kerja maksimum 3 (tiga) jam, dilakukan pada siang hari dan tidak mengganggu waktu sekolah, keselamatan dan kesehatan kerja, adanya hubungan kerja yang jelas, 
dan menerima upah sesuai dengan ketentuan yang berlaku. Bagi pengusaha yang melanggar persyaratan-persyaratan ruang lingkup pekerjaan ringan bagi pekerja anak dapat dikenakan sanksi pidana penjara paling singkat 1 (satu) tahun dan paling lama 4 (empat) tahun dan/atau denda paling sedikit Rp 100.000.000,- (seratus juta rupiah) dan paling banyak Rp 400.000.000,- (empat ratus juta rupiah).

Kemudian, pekerja anak yang bekerja di tempat kerja yang merupakan bagian dari kurikulum pendidikan atau pelatihan yang disahkan oleh pejabat yang berwenang adalah anak yang berumur paling sedikit 14 (empat belas) tahun. Namun, pengusaha yang bersangkutan harus memberikan petunjuk yang jelas tentang cara pelaksanaan pekerjaan serta bimbingan dan pengawasan dalam melaksanakan pekerjaan dan memberikan perlindungan keselamatan dan kesehatan kerja. Selanjutnya, mengenai pekerja anak yang bekerja untuk mengembangkan bakat dan minatnya; pengusaha wajib memenuhi persyaratan yaitu pekerjaan dilakukan di bawah pengawasan langsung dari orang tua atau wali, waktu kerja paling lama 3 (tiga) jam sehari, dan kondisi serta lingkungan kerja tidak mengganggu perkembangan fisik, mental, sosial, dan waktu sekolah.

Bagi pengusaha yang melanggar ketentuan di atas akan dikenakan sanksi pidana kurungan paling singkat 1 (satu) bulan dan paling lama 12 (dua belas) bulan dan/atau denda paling sedikit Rp 10.000.000,- (sepuluh juta rupiah) dan paling banyak Rp 100.000.000,(seratus juta rupiah). Selanjutnya, perihal pekerja anak yang dipekerjakan bersama-sama dengan pekerja atau buruh dewasa; harus dipisahkan dari tempat kerja pekerja/buruh dewasa. Hal tersebut perlu dilakukan agar anak masih dapat merasakan tubuh kembang kehidupannya. Di sisi lain, hal tersebut dapat memberikan 
dampak psikologi yang baik bagi anak; sehingga anak tidak merasa depresi dan bisa menjalankan segala sesuatunya dengan baik.

Perlindungan anak bukan hanya di atur dalam UU Ketenaker. Pasal 20 UU Anak II juga menyebutkan bahwa Negara, pemerintah, pemerintah daerah, masyarakat, keluarga, dan orang tua atau wali berkewajiban dan bertanggung jawab terhadap penyelenggaraan perlindungan anak. Ketentuan tersebut menyimpulkan bahwa perlindungan anak merupakan bagian penting yang harus diperhatikan oleh semua pihak yang terkait di dalamnya. Peraturan perundang-undangan yang mengatur masalah perlindungan anak tentu memiliki keterkaitan antara satu dengan yang lainnya;35 oleh karena sejatinya tujuan dari dibuatnya peraturan perundangundangannya tersebut adalah guna melindungi hak-hak yang di miliki oleh seorang anak.

Berbagai penjelasan di atas menunjukkan bahwa kesejahteraan pekerja anak akan didapatkan manakala hak-hak pekerja anak yang tercantum dalam berbagai peraturan perundang-undangan dipenuhi dan dijamin oleh perusahaan. Kesejahteraan dalam penelitian ini bukan hanya bermakna materiil, namun meliputi aspek non materiil; seperti halnya tetap memberikan keleluasaan bagi anak untuk senantiasa mengembangkan kapasitas dirinya. Bukan hanya itu, tingkat kesejahteraan pekerja anak dapat dikatakan dipenuhi apabila perusahaan memberikan batasan-batasan perihal teknis bekerja dari pekerja anak; sebagaimana ketentuan yang diatur dalam peraturan perundang-undangan. Kesejahteraan tersebut akan diraih oleh pekerja anak pula apabila mereka mendapatkan tindakan yang non

35 Noeke Sri Wardhani, Susi Ramadhani \& Lentiara Putri, “Tanggung Jawab Orang Tua dalam Permasalahan Pekerja Anak di Sektor Informal dalam Kajian Sosiologis Yuridis" (2020) 5:2 Univ Bengkulu Law J 119-136. 
diskriminasi; seperti halnya pengupahan yang layak, jenis pekerjaan yang proporsional (tidak terlalu berat), dan lain sebagainya.

Perihal keadilan, pekerja anak patut diberikan perlindungan hukum pula; mengingat anak adalah manusia yang memiliki hak asasi. Bagaimanapun, anak adalah masa depan bangsa; yang berarti pembangunan bangsa dalam berbagai aspek akan didorong dan diinisiasi oleh para penerus bangsa. Selanjutnya, perlindungan hukum pekerja anak merupakan tanggung jawab moral negara; oleh sebab negara memiliki peran untuk memberikan jaminan hidup seluruh lapisan masyarakat.

\section{UPAYA PENANGGULANGAN PERMASALAHAN PEKERJA ANAK}

Penanganan pekerja anak di dilakukan dengan tiga upaya. Pertama, upaya preventif. Upaya tersebut dimaksudkan untuk mencegah bertambahnya jumlah pekerja anak yang bekerja pada bentuk-bentuk pekerjaan terburuk. Oleh sebab itu, bentuk perlindungan terhadap pekerja anak dapat dilakukan oleh pemerintah dengan cara melakukan pengawasan. Upaya tersebut lumrah dilakukan oleh Pegawai Fungsional Pengawas Ketenagakerjaan (PFPK) yang melakukan pemantauan secara rutin dan berkala terhadap para perusahaan. Namun, upaya preventif yang dilaksanakan oleh PFPK masih sebatas pada pemantauan terhadap perusahaan yang berbadan hukum. Sedangkan pemantauan bagi perusahaan yang tidak berbadan hukum masih belum dilaksanakan secara rutin; mengingat masih terbatasnya sumber daya yang dimiliki oleh bidang perlindungan ketenagakerjaan Disnakertrans. Selain itu, sumber daya manusia maupun sumber daya modal atau keuangan berupa 
minimnya penganggaran serta kendala kondisi geografis juga menjadi penyebabnya minimnya pengawasan.

Kedua, upaya kuratif. Disnakertrans memiliki program penanganan secara kuratif yang terintregasi melalui peran aktif multi-stakeholders. Program tersebut adalah Program Pengurangan Pekerja Anak dalam mendukung Program Keluarga Harapan (PPA-PKH). Kegiatan tersebut dirancang sebagai kegiatan terintegrasi (bersinergi) dengan Program Keluarga Harapan (PKH) untuk mengembalikan anak bekerja dan tidak bersekolah kembali ke pendidikan. Kegiatan ini diimplementasikan dengan melibatkan berbagai instansi baik pemerintah maupun non-pemerintah termasuk Lembaga Swadaya Masyarakat.

Bantuan pendanaan melalui program di atas merupakan bantuan dari pemerintah pusat; dalam pelaksanaannya Kementerian Tenaga Kerja dan Transmigrasi menyerahkan kepada pemerintah daerah yang telah ditunjuk melalui dinas yang membidangi ketenagakerjaan. Multi-stakeholders pada kegiatan PPA-PKH mempunyai peran yang sangat penting; mengingat keperluan koordinasi adalah pilar yang sangat penting untuk kelanjutan suatu program kerja. ${ }^{36}$ Tingkat keberhasilan dari program ini akan diukur dari sejauh mana masing-masing stakeholders yang terlibat untuk berkoordinasi serta bekerjasama secara sinergi dalam mengurangi pekerja anak dan mengembalikan mereka untuk melanjutkan pendidikannya.

Ketiga, upaya represif. Penindakan atau penjatuhan sanksi oleh Disnakertrans terhadap perusahaan yang tidak taat terhadap peraturan perundang-undangan dilegitimasi oleh UU Ketenaker.

${ }^{36}$ Mifta Farid, Antikowati Antikowati \& Rosita Indrayati, "Kewenangan Pemerintah Daerah dan Partisipasi Masyarakat dalam Pengelolaan Potensi Daerah" (2017) 4:2 e-Journal Lentera Huk 95. 
Upaya represif adalah upaya terakhir yang harus dilakukan; mengingat upaya tersebut merupakan upaya perencanaan secara terpadu mengenai keabsahan pekerja anak, khususnya perlindungan atau penjaminan atas hak dan kewajiban pekerja anak.

Perencanaan merupakan kunci penting bagi suatu proses yang berkesinambungan dari waktu ke waktu. Terlebih, perencanaan tersebut dilakukan secara terpadu (comprehensive planning). Hal tersebut dapat dilakukan dengan beberapa langkah. Pertama, penerapan perencanaan partisipatif; yang dalam arti yang sebenarnya melibatkan seluruh stakeholder yang terkait dengan sektor yang dibahas. Kedua, meningkatkan efektivitas pada tataran sektor atau di lingkungan pemerintah guna melakukan terobosan-teroban terhadap strategi yang akan dilakukan untuk pencapaian targettarget tersebut. Ketiga, sinkronisasi national planning maupun regional planning. Isu pembangunan nasional maupun regional perlu dijabarkan serta disinergikan dengan kepentingan-kepentingan yang akan dilaksanakan pusat; baik program yang dilaksanakan oleh instansi vertikal maupun instansi horizontal di lingkungan pemerintah daerah. Keempat, sinkronisasi antara planning dan budgeting.

Prinsip perencanaan untuk penanganan pekerja anak tidak terlepas dari berbagai hak-hak fundamental anak. Pertama, hak untuk hidup; yang bermakna bahwa setiap anak berhak untuk mendapatkan kehidupan yang layak dan terpenuhinya kebutuhan-kebutuhan dasar mereka termasuk tempat tinggal, makanan dan perawatan kesehatan. Kedua, hak untuk berkembang. Maksud dari hak untuk berkembang disini adalah bahwa setiap anak berhak untuk tumbuh dan berkembang secara wajar tanpa halangan. Mereka berhak mengetahui identitasnya, mendapatkan pendidikan, bermain, beristirahat, bebas mengemukakan pendapat, memilih agama, 
mempertahankan keyakinan, dan semua hak yang memungkinkan mereka berkembang secara maksimal sesuai potensinya.

Ketiga, hak untuk mendapat perlindungan. Maksud dari hak untuk mendapat perlindungan adalah bahwa setiap anak berhak mendapat perlindungan dari perlakuan diskriminasi, eksploitasi baik ekonomi maupun seksual, penelantaran, kekejaman, kekerasan, penganiayaan, ketidakadilan, dan perlakuan salah. Keempat, hak untuk berperan serta. Maksud dari hak berperan serta disini adalah setiap anak berhak untuk berperan aktif dalam masyarakat; termasuk kebebasan untuk berekspresi, kebebasan untuk berinteraksi dengan orang lain, dan menjadi anggota suatu perkumpulan. Kelima, hak untuk memperoleh pendidikan. Setiap anak berhak memperoleh pendidikan, minimal tingkat dasar. Bagi anak yang terlahir dari keluarga yang tidak mampu dan yang tinggal Perencanaan Terpadu Penanganan Pekerja Anak, pemerintah berkewajiban untuk bertanggungjawab untuk membiayai pendidikan mereka.

Upaya perencanaan terpadu harus dilakukan dengan suatu tujuan bersama serta keterkaitan antar sasaran dalam pencapaian tujuan bersama. Di sisi lain, penerapan multi disiplin keilmuan dan penegasan hak dan kewajiban terkait dengan para stakeholder akan menumbuhkan sikap proaktif pada setiap pemangku kepentingan. Keterkaitan antar tahap proyek dalam siklus proyek juga tak kalah penting; mengingat dalam dunia kerja, terdapat keterkaitan antar input sumber daya serta output kegiatan. Penerapan pendekatan sistem berkelanjutan akan memberikan dorongan pengelolaan operasional pekerjaan dilaksanakan secara efisien dan efektif. Bukan hanya itu, perencanaan terpadu akan menumbuhkan sinergitas dalam pengelolaan masingmasing unsur; yang menyasar keterkaitan dalam penyusunan antar program dan sistem monitoring serta evaluasi. Tak hanya itu, perencanaan terpadu akan mendorong 
terjadinya koordinasi dan sinkronisasi guna mewujudkan pendekatan yang holistik dan humanis.

Bukan hanya dari berbagai upaya yang telah di uraikan di atas, Negara memiliki peran penting pula perihal penanggulangan permasalahan perlindungan hukum bagi pekerja anak. Negara sebagai penanggung jawab perlindungan secara moral dan material terhadap masyarakatnya harus mampu mengambil kebijakan; baik secara yuridis maupun sosial dalam rangka melindungi hak anak dari eksploitasi ekonomi. Langkah tersebut tentunya termasuk harmonisasi hukum nasional terhadap instrumen hukum internasional yang mengatur perlindungan anak dari eksploitasi ekonomi; sebagaimana hal tersebut terdapat dalam UU HAM yang merupakan 'Undang-undang organik' tentang perlindungan hak asasi manusia dari UUD NRI 1945.

Rumusan mengenai hak anak disebutkan dalam Pasal 52 UU HAM yang menyatakan bahwa setiap anak berhak atas perlindungan orang tua, keluarga, masyarakat, dan negara. Selain itu, Pasal 52 UU HAM juga menyebutkan bahwa hak anak adalah hak asasi manusia; sehingga demi kepentingan anak, hak tersebut harus diakui dan dilindungi oleh hukum, bahkan sejak dalam kandungan. ${ }^{37}$ Tidak hanya itu, Pasal 58 UU HAM menyebutkan pula bahwa setiap anak berhak untuk mendapatkan perlindungan hukum dari segala bentuk kekerasan fisik atau mental, penelantaran, perlakuan buruk, dan pelecehan seksual selama dalam pengasuhan orang tuanya atau walinya, atau pihak lain manapun yang bertanggung jawab atas pengasuhan anak tersebut.

37 Fransiska Novita Eleanora \& Lusia Sulastri, "Revitalisasi Perlindungan Anak dan Perempuan Menuju Pembangunan Berkelanjutan (Sustainable Development Goals)" (2020) 3:2 Widya Yuridika 217. 
Pasal 64 dan Pasal 65 UU HAM juga memuat ketentuan perlindungan anak; terutama dalam bentuk perlindungan terhadap anak sebagai pekerja. Pasal 64 UU HAM memberikan hak kepada anak untuk memperoleh perlindungan dari kegiatan eksploitasi ekonomi dan setiap pekerjaan yang membahayakan dirinya; sehingga dapat mengganggu pendidikan, kesehatan fisik, moral, kehidupan sosial, dan mental spritualnya. dan Pasal 65 UU HAM juga memberikan hak atas anak untuk memperoleh perlindungan dari kegiatan eksploitasi dan pelecehan seksual, penculikan, perdagangan anak, serta dari segala bentuk penyalahgunaan narkotika, psikotropika, dan zat adiktif lainnya. Hal lain yang tidak kalah penting untuk di diperhatikan adalah peningkatan pengetahuan ketenagakerjaan dari sisi masyarakat juga. Selama ini, pemahaman masyarakat terhadap pengetahuan ketenagakerjaan dapat dikatakan sangat rendah; ${ }^{38}$ bahkan hampir dapat dikatakan tidak ada. Hanya kelompok masyarakat menengah ke atas saja yang memahami tentang pengaturan masalahan ketenagakerjaan.

Fenomena di atas disebabkan oleh kurangnya pemahaman masyarakat terhadap masalah ketenagakerjaan ini. Peraturan perundang-undangan ketenagakerjaan tidak hanya semata-mata mengatur hak dan kewajiban antara pengusaha dan pekerja saja; tetapi memperhatikan keselamatan dan kesehatan si pekerja pula. Oleh sebab, pada konsep hubungan industrial; ${ }^{39}$ tujuan pengaturan ketenagakerjaan untuk melindungi tenaga kerja dan menempatkan posisi pekerja sederajat dengan pegusaha, sehingga pekerja

38 Krisna Praditya Saputra, Susilo Wardani \& Selamat Widodo, "Pelaksanaan Pemenuhan Jaminan Sosial Ketenagakerjaan Bagi Juru Parkir Resmi di Kabupaten Banyumas" (2020) 19:2 Kosmik Huk 123-132.

39 Anak Agung Prabhaputra, I Nyoman Putu Budiartha \& I Putu Gede Seputra, "Sistem Outsourcing dalam Hubungan Industrial di Indonesia" (2019) 1:1 J Analog Huk 22-27. 
merupakan partner dari pengusaha. Tidak akan ada artinya pengusaha tanpa pekerja, dan sebaliknya pekerja tidak akan dapat bekerja tanpa pengusaha. ${ }^{40}$ Oleh karena itu, keseimbangan antara hak dan kewajiban pengusaha dan pekerja harus benar-benar ada agar tercipta hubungan saling menguntungkan di antara kedua belah pihak.

Berbagai peraturan perundang-undangan ketenagakerjaan telah dibentuk dan diberlakukan oleh pemerintah sebagai instrumen perlindungan hukum terhadap hak pekerja. ${ }^{41}$ Oleh karena itu, masyarakat seharusnya mengetahui peraturan yang terdapat dalam UU Ketenaker tersebut. Sehingga, manakala masyarakat mengetahui pengaturan hukum yang terdapat dalam UU Ketenaker, akan tercipta peningkatan kegiatan hukum berupa penyuluhan maupun seminar mengenai perlindungan anak itu sendiri. Sebagaimana diketahui, pada saat ini telah banyak peraturan perundangundangan yang terkait dengan perlindungan hak-hak anak dan juga lembaga-lembaga yang medukung upaya perlindungan anak ini; ${ }^{42}$ seperti Komisi Nasionas Anak (Komnas Anak), Komisi Perlindungan Perempuan dan Anak (KPPA), serta sejumlah lembaga swadaya masyarakat.

Lembaga ini secara aktif harus didorong untuk terus melakukan kegiatan sosialisasi. Hal tersebut bertujuan untuk pengembangan

40 Hazar Kusmayanti, Agus Mulya Karsona \& Efa Laela Fakhriah, “Penyelesaian Perselisihan Hubungan Industrial Melalui Putusan Perdamaian di Pengadilan Hubungan Industrial Pengadilan Negeri Padang Kelas I (A)" (2020) 6:1 J Huk Acara Perdata 35-54 at 48.

41 Vicko Taniady et al, "PHK dan Pandemi Covid-19: Suatu Tinjauan Hukum Berdasarkan Undang-Undang Tentang Ketenagakerjaan di Indonesia” (2020) 4:2 J Yustisiabel 97.

42 Kayus Kayowuan Lewoleba \& Muhammad Helmi Fakhrazi, "Studi FaktorFaktor Terjadinya Tindak Kekerasan Seksual Pada Anak-Anak" (2020) 2:1 Esensi Huk 27-48 at 32. 
kelembagaan dengan segala aktivitasnya; yang diharapkan dapat menghapus atau setidaknya mengurangi jumlah pekerja anak. Pembentukan lembaga tersebut dipandang sebagai mekanisme kontrol yang paling baik dalam rangka mencegah pelanggaran terhadap peraturan perundang-undangan yang berlaku. Bukan hanya itu, hadirnya lembaga-lembaga pemerhati anak ini lebih tepatnya berfungsi sebagai kontrol sosial atau kontrol masyarakat terhadap kebijakan pemerintah sekaligus pelaksanaan kebijakan pemerintah yang baik oleh perusahaan maupun pemerintah sendiri itu sendiri.

Selain pengawasan, hal yang tidak kalah penting harus dilakukan dalam rangka memberikan rasa perlindungan bagi pekerja anak adalah pembinaan terhadap pengusaha dalam hubungannya dengan masalah ketenagakerjaan. Dengan demikian, pengusaha diharapkan mampu memahami peraturan perusahaan dan masalah ketenagakerjaan; sehingga terkait dengan pekerja anak ini, pengusaha dapat memahami karakterisitk pengaturan pekerja anak, seperti ketentuan larangan mempekerjakan anak. Sehingga, pengusaha dapat mencegah pekerja anak. Apabila terpaksa mempekerjakan anak, pengusaha dapat mencegah adanya bentukbentuk pekerjaan terburuk bagi anak sebagaimana diatur di dalam ketentuan Pasal 74 UU Ketenaker serta peratuan perundangundangan lainnya yang berhubungan dengan perlindungan anak atau pekerja anak.

\section{KESIMPULAN}

Anak-anak diperbolehkan bekerja dengan syarat harus memenuhi kriteria yang telah diuraikan dalam UU Ketenaker. Sehingga, anakanak senantiasa dapat menjalankan pendidikannya, walaupun 
mereka bekerja. Bila hal ini dilakukan sesuai dengan aturan yang berlaku, maka kendala-kedala yang dijumpai sebelumnya pada penanganan pekerja anak dapat diatasi dengan lebih baik sesuai dengan peraturan perundang-undangan ketenagakerjaan yang berlaku. Bukan hanya itu, keadilan serta kesejahteraan bagi pekerja anak tersebut akan terwujud apabila seluruh pihak bersama-sama mendorong terciptanya perencanaan dan implementasi berkelanjutan mengenai pekerja anak.

\section{DAFTAR PUSTAKA}

Gosita, Arif, Masalah perlindungan Anak (Jakarta: Sinar Grafika, 1992). Marzuki, Peter Mahmud, Penelitian Hukum: Edisi Revisi, 13th ed (Jakarta: Kencana, 2017).

Agusmidah, Agusmidah \& Suria Ningsih, "A Critical Review of Waging in Indonesian Law" (2016) 3:2 Rechtsidee 61.

Banjarani, Desia Rakhma \& Ricco Andreas, "Perlindungan dan Akses Hak Pekerja Wanita di Indonesia: Telaah Undang-Undang Nomor 13 Tahun 2003 tentang Ketenagakerjaan Atas Konvensi ILO" (2019) 10:1 J HAM 115.

Cooper, James, "Child Labour: Legal Regimes, Market Pressures, and the Search for Meaningful Solutions" (1997) 52:3 Int J 411.

Daalen, Edward van \& Karl Hanson, “The ILO's Shifts in Child Labour Policy: Regulation and Abolition" (2019) 1:11 Rev Int Polit développement 133-150.

Danayanti, Sri Intan \& I Gusti Ngurah Wairocana, "Perlindungan Hukum Terhadap Anak di Bawah Umur yang Berprofesi sebagai Artis Berdasarkan Undang-Undang Ketenagakerjaan" (2019) 7:7 Kertha Semaya J Ilmu Huk 1.

Eleanora, Fransiska Novita \& Lusia Sulastri, “Revitalisasi Perlindungan Anak Dan Perempuan Menuju Pembangunan 
Berkelanjutan (Sustainable Development Goals)" (2020) 3:2 Widya Yuridika 217.

Endrawati, Netty, "Perlindungan Hukum Terhadap Pekerja Anak di Sektor Informal (Studi Kasus Di Kota Kediri)" (2012) 12:2 J Din Huk.

Farid, Mifta, Antikowati Antikowati \& Rosita Indrayati, "Kewenangan Pemerintah Daerah dan Partisipasi Masyarakat dalam Pengelolaan Potensi Daerah" (2017) 4:2 e-Journal Lentera Huk 95.

Fitriani, Rini, "Peranan Penyelenggara Perlindungan Anak dalam Melindungi dan Memenuhi Hak-Hak Anak" (2016) 11:2 J Huk Samudra Keadilan 250-258.

Hardono, Pita Jubaningtyas, "Perlindungan Hukum Terhadap Pekerja Anak Terkait Upah dan Jam Kerja" (2019) 1:2 JuristDiction 675.

Hastarini, Arvita, "Keabsahan Perjanjian Kerja yang Dilakukan Anak di Bawah Umur" (2019) 25:1 J Wacana Huk 19.

Holzscheiter, Anna, Jonathan Josefsson \& Bengt Sandin, "Child Rights Governance: An Introduction" (2019) 26:3 Childhood 271-288.

Islam, Mohammad Shahidul \& Md Abdur Rakib, "Labour Laws in the Garment Sector of Bangladesh: a Workers' View" (2019) 34:3 Yuridika 467.

Izziyana, Wafda Vivid, "Perlindungan Hukum Bagi Pekerja Anak di Indonesia" (2019) 3:2 Leg Standing J Ilmu Huk 103.

Kayowuan Lewoleba, Kayus \& Muhammad Helmi Fakhrazi, “Studi Faktor-Faktor Terjadinya Tindak Kekerasan Seksual Pada Anak-Anak" (2020) 2:1 Esensi Huk 27-48.

Kusmayanti, Hazar, Agus Mulya Karsona \& Efa Laela Fakhriah, "Penyelesaian Perselisihan Hubungan Industrial Melalui Putusan Perdamaian di Pengadilan Hubungan Industrial Pengadilan Negeri Padang Kelas I (A)" (2020) 6:1 J Huk Acara 
Perdata 35-54.

Kusuma, Nada \& Santoso Tri Raharjo, “Penanganan Masalah Pekerja Anak Melalui Pemberdayaan Organisasi Lokal 'Forum Peduli Anak' di Kelurahan Cibeureum Kota Cimahi" (2016) 6:1 Share Soc Work J.

Liebel, Manfred, "Protecting the Rights of Working Children Instead of Banning Child Labour" (2015) 23:3 Int J Child Rights 529-547.

Lubis, Hasrul Mahadi \& Arifin Saleh, "Pekerja Anak sebagai Buruh Batu Bata di Kelurahan Silandit Kota Padang Sidimpuan" (2020) 1:1 J Interv Sos dan Pembang 29-43.

Mulyanto, Kartika Dewi, “Urgensi Ratifikasi Konvensi Pekerjaan yang Layak bagi Pekerja Rumah Tangga oleh Pemerintah Indonesia" (2018) 1:1 Undang J Huk 109-133.

Prabhaputra, Anak Agung, I Nyoman Putu Budiartha \& I Putu Gde Seputra, "Sistem Outsourcing dalam Hubungan Industrial Di Indonesia" (2019) 1:1 J Analog Huk 22-27.

Prajnaparamita, Kanyaka, "Perlindungan Tenaga Kerja Anak" (2018) 1:2 Adm Law Gov J 215-230.

Saputra, Krisna Praditya, Susilo Wardani \& Selamat Widodo, "Pelaksanaan Pemenuhan Jaminan Sosial Ketenagakerjaan Bagi Juru Parkir Resmi di Kabupaten Banyumas" (2020) 19:2 Kosmik Huk 123-132.

Şişli, Zeynep \& Stephanie A Limoncelli, “Child Brides or Child Labor in a Worst Form?" (2019) 22:2 J Labor Soc 313-324.

Sohidin, "Faktor Demografi yang Mempengaruhi Pekerja Anak di Provinsi Kepulauan Bangka Belitung Tahun 2018" (2020) 19:1 J Penelit Kesejaht Sos 45-82.

Swastika, Made Dharma Laksana, I Nyoman Putu Budiartha \& Desak Gede Dwi Arini, "Perlindungan Hukum bagi Pekerja Anak di Indonesia" (2020) 1:1 J Interpret Huk 101-105.

Taniady, Vicko et al, "PHK dan Pandemi Covid-19: Suatu Tinjauan 
Hukum Berdasarkan Undang-Undang Tentang Ketenagakerjaan Di Indonesia" (2020) 4:2 J Yustisiabel 97.

Wardhani, Noeke Sri, Susi Ramadhani \& Lentiara Putri, “Tanggung Jawab Orang Tua dalam Permasalahan Pekerja Anak di Sektor Informal dalam Kajian Sosiologis Yuridis" (2020) 5:2 Univ Bengkulu Law J 119-136.

Winda Aditya Putra, I Gusti Ngurah, I Nyoman Putu Budiartha \& Luh Putu Suryani, "Akibat Hukum Pekerja Anak Menurut Undang-Undang Nomor 13 Tahun 2003" (2021) 2:1 J Konstr Huk 57-61.

Sulistiyono, Tri \& Lowrenszya Siagian, The Phenomenon of Child Labour: Causes, Consequences, and Protection under Indonesian Law (Paris, France: Atlantis Press, 2019). 